Appraisal and the Future of Archives in the Digital Era

Richard J. Cox

University of Pittsburgh School of Information Sciences

Introduction. It is risky to predict the future, especially in the volatile information professions, but it is always fun to try. Some make wild predictions with the assurance they won't be around to be held accountable for their predictions. David Friedman states that the "future is radically uncertain," (Friedman, 4) basing this on what is presently happening with intellectual property, personal privacy, transparency and its mixed blessings, e-business, open space and scholarship, computer crime, biotechnology, and virtual reality - all issues with implications for what archivists do, especially the critical aspect of their work as appraisers and documenters. Archival appraisal is also the task that might seem to be completely contrary to where we are heading in the digital era, as some predict that a hallmark of our future may be a new ability to save everything (ending any need for selection).

In this essay I try to do a few basic things. First, I attempt to characterize how information technologies are transforming our world. Second, I make a brief case for why appraisal is the central and most important archival function. Third, I try to relate the new digital technologies to archival appraisal (and vice versa), making a case for how more rigorous archival appraisal must become, speculating about the archivist of the future.

The World Flashes By. The world of the archivist has changed substantially in the past generation. My career is now well into its fourth decade, and the challenges today are remarkably different from the ones I first faced in the early 1970s. When I 
started work, we had no computers, answered queries by telephone and postal mail, provided reference service during certain hours on certain days, distributed finding aids in printed form, and dealt mostly with paper-based materials. Today, the typical archivist stares at a computer screen most of the day, provides answers to queries via e-mail, answers reference questions on an almost $24 / 7$ basis, distributes finding aids on the World Wide Web, and works with an increasing array of digitally-born documentary materials. The archival universe is populated with Blackberries, iPods, cell phones, GPS navigation systems, Flickr, blogs, MySpace, Wikis, flash mobs, open source software, digital cameras, GPS trackers, YouTube, and FaceBook (just for starters).

Emerging information technologies suggest major issues for archivists.

Researchers, relying on online sources, may cease visiting physical spaces or even the use of traditional documentary materials housed in physical repositories (unless major digitalization efforts are undertaken (see Howard) or there are renewed efforts to teach information literacy skills [see Rein; Snelson]). The persistent archival paradigm has been the archives as a place to be visited in person based on the collecting of documentary artifacts, but this looks uncertain in the future (leading some to defend real library and archives spaces as necessary places for contemplation) (Levy). Anyone who has done research in an archives will tell you it is a contemplative process, where you work carefully through masses of letters, diary entries, or accounting ledgers, listening for the voices from the past. Reflection is the order of the day, a process that is different from Web searching where speed and efficiency is often the primary objective.

New forms of digital scholarship are emerging, requiring new and different kinds of digital repositories like we have never envisioned before, with a greater commitment 
to open access (Borgman). In effect, archivists, and other professionals, need to socialize these information technologies, as Donald Norman argues, in order to make the machines "truly useful" (Norman, 172 -173). What will be the role of the archivist in accomplishing this? How will archivists cross boundaries they have been reluctant to cross in the past, building new kinds of mental landscapes (see Gardner, identifying five cognitive abilities that we need to develop and nurture).

Cautionary voices, advocating the need for both traditional and digital archives and libraries, are often lost in the crush of the many voices championing the virtual rather than physical spaces (see, for example, Darnton). While archivists might be tracking the impact of digital natives (individuals who have grown up with the Internet) whose ideas of archives are only what they can access online, universities are developing new forms of information competency programs, with some professors taking online systems into their classrooms directly to the students will find (Guess, 17 June 2008). The new information technologies suggest ways for people to work together in groups and organizations to manage differently, all built around concepts such a knowledge commons (Hess and Ostrom; Shirky). Archivists can utilize these new technologies in innovative ways to reach their research communities and the public, assuming archivists themselves have gained a sufficient understanding of the digital technologies.

There are many issues generated from the digital information technologies. The growing reliance on digital technologies, now some in their own right becoming older sources, requires careful maintenance of hardware, software, digital content - all posing technical standards perhaps requiring a nearly constant appraisal (see, for example, Andy Guess, July 23, 2008, commenting on a 2006 report from Britain’s Digital Preservation 
Coalition ). Librarians and archivists alike are reconsidering their own digitization efforts in light of large-scale commercial efforts by companies such as Google and Microsoft, especially as some abandon or scale back their efforts or become more proprietary about content (Guess, 30 May 2008). Nicholas Carr wonders if our immersion in networked communications isn't transforming the way we read or even what we read, hindering our ability to read longer texts and certain kinds of documents (Carr). If humanity's connection to text is altered, surely the manner in which it uses historical sources will change as well.

There are temptations for archivists in the Digital era, especially the claim that every document, book, article, work of art, and piece of ephemera will be digitized and placed on the Web (continuation of a historic quest to build a universal library or archive). Google, aiming to digitize all of the world's books, has drawn considerable commentary, most of it, at least by the public and the media, quite positive. Ian Wilson, the head of Canada's National Archives and Library, writes in an introduction to JeanNoël Jeanneney's book on Google, that Google's offer is “seductive to chronically underfunded libraries and archives, the custodians of our societies' cumulative documentary heritage. Jeanneney, president of France's National Library, contrasts the long-term cultural mission of librarians and archivists with the short-term business aims of Google, arguing that there is the need for a renewed commitment to the work of librarians (and by implication, archivists) to be not merely caretakers but to "stand beside professors and schoolteachers as essential intermediaries of knowledge" (Wilson in Jeanneney, 23). 
Not long ago digitization was seen as opposed to preservation, but this has shifted dramatically since then, partly because digitization's usefulness for enhancing access to our documentary heritage and partly because of progress in making digitization a more reliable approach for administering documents. Archivists and their tasks are being redefined. David Holdsworth, for examples, questions the need for selection, noting, "If it costs very little to keep digital data, we might resist the temptation to discard those items of little interest to us, but which later researchers might find valuable" (Holdsworth in Deegan and Tanner, 57). Some who believe in the possibility of saving everything are also advocates for "lifelogging," recording everything they do and say (and suggesting something about the future of public and personal archives) (Carlson).

There also are opportunities for archivists posed by the new information technologies. If Wikipedia has managed to take hold, there is reason to believe that other Web 2.0 technologies and social computing will have an impact on what archives do and how archivists operate (Wilson). The many charges leveled against Wikipedia, concerning its effort to give everyone a voice at the expense of its reliability, suggests caution with how archivists use social computing, perhaps with archivists teaching their researchers how to evaluate the quality of online resources (see, for example, Clifford). Archivists should make available draft appraisal reports and seek public input into these decisions. This will require archivists to be much more coherent in their appraisal practices, enriching society's knowledge of the archival mission and its significance.

The Digital Era also claims (or hopes) that amateurs will replace professional gatekeepers, although some have questioned the wisdom of this (Keen). Others have embraced the notion of professional convergence, a "state in which collaboration around 
a specific function or idea has become so extensive, engrained and assumed that it is no longer recognized by others as a collaborative undertaking. Instead, it has matured to the level of infrastructure and becomes, like our water or transportation networks, a critical system that we rely upon without considering the collaborative efforts and compromises that made it possible" (Zorich, Waibel, and Erway). The report provides a model for considering how convergence can occur, such as in coordinated searching and users being able to add knowledge via "social tagging or community annotation" (Zorich, Waibel, and Erway, 14). It is a brave new world, one where authors manage "open book" blogs, inviting commentary by other experts and the public. Perhaps archivists can write drafts of both theoretical and practical volumes in blogs and Wikis to generate a lot more openness about their foundational knowledge. Some of my writing in the past few years has derived from my writing in a blog, but very few archivists participate by providing comments (in fact, I get more comments from those interested in archives from outside the field). Are archivists ready yet for the Digital Era?

The greatest challenge for archivists may be generational issues. Many archivists working today did not grow up with a rich array of information technologies, but now they are working with the first generation of digital natives (Palfrey and Gasser). We need to be cautious not to get ahead of ourselves. Peter Shillingsburg reminds us that we are "but 15-20 years into an era whose counterpart introduced a 500-year reign" (Shillingsburg, 4)). Alistair Tough and Michael Moss believe recordkeeping to be a "relatively new field of study," with "boundaries . . poorly defined and porous," typical of "emerging disciplines" (Tough and Moss, ix). Seamus Ross thinks we have overstated the fragility of the digital materials, when the more serious problem is the lack of 
collaboration among records professionals, IT workers, and managers (Ross in Tough and Moss). Archivists are not working in a static world and or relying on static principles. A lot of archival angst generated by the Digital Era relates more to professional status and authority, than the basic nature of archival work, challenging old comfort zones. There may be new careers out there, incorporating archival functions, such as in "digital data management" or "data curation" (National Science Foundation).

Digitizing documentary sources prompts questions about the appraisal function. Selection is hindered by the fact that we can never fully anticipate the use of anything in the future. Does this mean that archivists should be conservative or cautious in their approaches to using digitization (or in evaluating digitally-born materials)? As Deegan and Tanner suggest, archivists must understand the alternatives, the possibility of losing important stuff if no surrogates are created (Deegan and Tanner, 10). If archivists don't embrace digitization fully, will they see their holdings neglected (as researchers and scholars go elsewhere, namely on-line, to find sources in more convenient ways)? Probably.

The potential loss of our digital documentary heritage draws more public attention (and sometimes major national funding, such as in the National Digital Information Infrastructure and Preservation Program) than the possibility that the new technologies allow us to save everything. Estimates about the growth of information and data may be difficult to make, but they are always impressive and capture our attention. Alex Wright reminds us that we now write "more than five exabytes worth of recorded information per year ... more than 50, 000 times the number of words stored in the Library of Congress, or more than the total number of words ever spoken by human beings" (Wright, 6). This 
speed of growth today is impressive. Wright writes, "Twenty years after Johannes Gutenberg invented his printing press, a bare handful of people in Germany and France had ever seen a printed book. Less than 20 years after its invention, the World Wide Web has touched billions" (Wright, 229). Surely, the world archivists worked in during the past few generations is disappearing (or, maybe is gone already).

The challenges to archival appraisal in the Digital Era seem well defined. We may see a decline in personal visits and the rise of a new kind of cyber-researcher, the loss of reflection or contemplation in archival research rooms, social computing approaches requiring the archivist to be more engaged with their real and potential researchers than ever before, the fashioning of new varieties of information literacy, different interactions with texts affecting why and how people use archival sources, new pressures generated from commercial enterprises in the digitization of the world's documentary sources, access trumping preservation in the question of digitization, demands for archivists to be more coherent and publicly open about how they conduct appraisal, archivists clarifying their claims as experts, archival discussions about their knowledge and practice on the Web, the coming of age of digital natives with very different expectations of archives (and museums and libraries), and the emerging of new disciplines (maybe digital curators?). These are all tantalizing issues to consider. And all of them suggest moving appraisal to the forefront of archival activities, because appraisal is a distinctive archival task.

Appraisal as the Core Archival Activity. Appraisal is easily defined as the "process of evaluating actual or potential acquisitions to determine if they have sufficient long-term research value to warrant the expense of preservation by an archival 
repository" (Ham, 2). Archivists have long understood that managing both their programs and their share of the documentary universe implies setting appraisal and acquisition objectives, measuring success in meeting those objectives, and revising objectives as progress is attained (Bearman). Such basic definitions are widely accepted, but in the Digital Era it also generates questions. Given the scale of the documentary universe, and its rapid expansion, can archivists really apply appraisal processes to it? Given the nature of the digital documentation, can archives acquire such sources as they have other materials in the past?

While appraisal may be essential, the contentious issue of the re-appraisal of documentary sources suggests that archivists have not resolved everything (Haas; Powell; Greene; Daniels-Howell ). Archivists have lamented that they lack a coherent approach to appraisal, or that it is more art than science (Sink; Rapport). Starting about a quarter of a century ago or more, archivists began to reveal how complicated appraisal is (Cook, 1992) and how messy the notion of the archive can be (Ketelaar; Foote, Bradley; Schwartz and Cook). Recent writings about archival appraisal have been influenced by postmodernism, playing with the elusive nature of truth and evidence (Cook, 2001; MacNeil; Nesmith). Postmodernism perhaps possesses its greatest significance for understanding the symbolic role of archives in society, and, by extension, better understanding of the appraisal function because this perspective shows appraisal to be an endlessly complex activity.

Such challenges have led a number of archivists to articulate better the role and process of appraisal (such as Schaeffer; Brown). The complexity of archival appraisal suggests the need for a great deal more analysis -- by archivists, by those who 
use archival materials, and by those studying the creation of documentary and information systems and the evolution of cultural organizations. Is there a single model or scheme guiding archival appraisal? How does preservation fit into appraisal? Does the continuing shift to digital records and information systems change the nature of the appraisal application? Is appraisal as much about saving artifacts as anything else? Is there an inherent societal impulse to do the opposite of the archival appraisal approach, that is, destroy the recorded past? How does non-traditional sources fit into the appraisal scheme? How does archival appraisal relate to the records management approaches? Are archivists doing well in documenting themselves and the appraisal function? Is reappraisal a legitimate archival activity? Can appraisal only be carried out in a cooperative fashion? And has the emergence of new personalized information technologies made obsolete the appraisal responsibility? Given the centrality of appraisal to all things archival, it is surprising that we still possess so many questions and issues, although this is both an attribute of the complexity of archival appraisal as a task and the ever-changing features of recordkeeping systems in our organizations and society. It is what makes archival work so intellectually engaging (whether one wants to be so engaged or not).

To understand how the emerging Digital Era has affected the archival community and its mission, it is critical to consider the impact on appraisal. When the modern archival profession took root, the focus seemed to be on acquiring everything and anything, something that is still prevalent among some practitioners (where the emphasis has been more on keeping than selecting). Thirty years ago, David Gracy wrote, likened it to a "vacuum cleaner" and termed it "unrealistic" (Gracy, 22). Given some of the 
renewed claims that everything can be saved, maybe this is not the case for twenty-first century materials. In the not so distant past, archivists worried about how they competed with each other (Ericson in Jimerson), but today that competition might not be among archives but between archives and non-archival web sites featuring documentary sources. Archivists, just like every other human being, like to accumulate possessions, and not always in a fashion that can be described rationally. Eventually, methodologies, such as the archival documentation strategy, were developed to encourage cooperation, recognizing the documentary universe is complex and becoming more complex (Samuels).

Archivists have been looking for better strategies in the appraisal and acquisition function for generations, understanding that the technologies of recordkeeping are not static, but evolving. Traditional ideas about the evidential and informational values of records may have contributed to the need for clearer methodology and more precise criteria; the older models of values are not only subjective, but they suggest the possibility that most everything ought to be preserved (because nearly any documentary scrap has potential value). What examining appraisal approaches usually tell us is that this is a responsibility that is always messier than one might imagine, if, for no other reason than that in appraising, records reflect all the problems and challenges of complex organizations and individual lives, even before considering the greater challenges of the Digital Era.

If grand appraisal schemes are worth pursuing, how should they be evaluated and, when necessary, re-evaluated? Often, archivists have tried to track trends in historical research, so that, when historians shift themes then archivists try to provide relevant 
documentation. In the Digital Era archivists could switch to gathering data in much greater detail than ever before about what researchers are doing (assuming, of course, that archivists have built the kinds of Web sites that allow such analysis). Many archives and archivists remain mostly reactive rather than proactive, seeing proposals for planned and analytical approaches to appraisal as too much for busy archivists (Abraham). Even with the massive quantity of records, in all media forms, the fear that some will be lost can lead to strange and poor appraisal decisions, often the result of lacking resources and strategies.

Archivists face many issues when they examine the documentary universe, due to its complexity and scale. Some of these challenges have been met, such as the development of sampling techniques (although it is difficult to gain a sense of just how well or often they are employed) (Kolish). Not everyone has been happy about the experimentation with new appraisal methodologies and models. However, whatever problems may result from archivists' efforts to be more pro-active in appraisal, to do otherwise creates a situation where the archivist is little more than a passive custodian (Booms). Archivists must have schemes when they approach the documentary universe, so it should be no surprise that some archivists also adopt the concept of saving everything, no matter how impractical this might be in reality.

Preservation is an old archival aim, and it has been seen as part of appraisal criteria. Earlier ideas associated copying, as in documentary editing, and accessioning, as in the movement of records to archival facilities, with preservation. When preservation is connected with a process of simply moving records into a facility, regardless of the condition of the facility, it is difficult to see a connection between preservation and 
appraisal. However, when preservation is focused on activities such as conservation treatment or digitization for enhanced access and reduction of wear on original sources, it is clearer that preservation is a selection function akin to appraisal.

Even though preservation and conservation approaches are a form of reappraisal, reselecting records for additional and more costly treatment or protection after their initial appraisal recognition as having value, it is difficult to discover much explicit writing about preservation as a criterion in appraisal theory or practice. Preservation, in archival appraisal, has always been an assumption, and writings about preservation have made few references to archival appraisal (Conway, 1990 and 1992; Boles and Young). How does any of this relate to the digital documentary universe and the archival mission?

Whether digitization will ever be universally accepted as a preservation mechanism or not, the point is that it is a necessity function. Most people and institutions have avoided the debate about this by focusing on matters such as using digitization to lessen the use of fragile originals. Many discussions occur as if everything can and will be digitized, but the greater likelihood is that there will always need to be some strategic criteria that can be easily understood, readily defended, and comfortably justified. Librarians and archivists alike have tried to develop reliable and verifiable selection criteria for preservation in general and digitization more specifically (Astle and Muir; Childs; Gertz; Hazen, Horrell, and Merrill-Oldham; de Stefano in Kenney and Rieger; and Vogt-O'Connor in Sitts). Embracing digitization, even while realizing its limitations, can be understood as just another stage in the effort both to preserve our documentary heritage and enhance meaningful access to it (Smith). Selection needs to be applied in 
experimental and testable ways in digitization projects, although it has been shoved aside by the attractive access enhancement aspects of placing digital materials on the Web.

There has been no resolution about digitization as preservation or access tool, but there have been a lot of interesting debates and cogent arguments. Although access seems to have been, thus far, the clear winner with digitization, librarians and archivists alike have sounded alarms about the implications of how they select items and collections for digitizing, usually with a focus on "commonly used materials" (Anderson, 76). Some have argued for risk management, considering the potential harm to or loss of archival and other valuable resources if some remedial action, such as digitization, is not taken. As digitization is increasingly applied, there is both a greater need to resolve the debates about what its purpose is, as well as to continue to test out technical solutions for its utility as a preservation mechanism.

While there has been tremendous discussion about appraisal, it was mostly a side issue to the concerns about whether archivists could preserve the digital documentary heritage. Archivists have been wringing their hands about how to identify, preserve, and administer electronic records for decades, contending both with the constantly changing technology and the explosion of records. Terry Cook recognizes the challenge of contending with the "billions of bytes" of scientific data with permanent value, while understanding that "no archives is equipped to acquire them directly" (Cook, 1991, Section 4.21). Archivists and records managers alike have speculated about how digital systems change the work, knowledge, and identity of records professionals (Stephens, 5). Archivists need to cooperate with information disciplines, from librarians to knowledge workers, while wrestling with new concepts, such as the records continuum, since records 
don't easily divide along specific phases of a life cycle because of their technological dependency (Cook, 1991, section 4.7; Upward and McKemmish).

At the heart of the challenge of the electronic documentary universe is the acknowledgement, grudgingly accorded, that the transformation from paper to digital has forced rethinking basic approaches and assumptions about the record or professional mission. In developing new approaches for selecting and managing the archival documentary universe, however, others have worried that the new approaches have excluded certain kinds of recordkeeping, such as personal archives (Cunningham). The search for practical archival approaches, with the understanding that many new recording technologies challenge the premises of these approaches, has stimulated rethinking about the nature of records and the evidence and information in these records. Sue McKemmish suggests that we need a "better understanding" of how documents operate (McKemmish, 36), while Verne Harris worries that her concept of "recordkeeping functionality" excludes what personal papers exist for and the purposes they serve (Harris, 12). What complicates all this is that individuals are increasingly creating personal archives directly in digital form.

The challenge posed by new information technologies may be defined, but the appraisal of digital records continues to be an area needing more experimentation, research, and success. As nearly every basic recording system we know about makes the transition into digital forms, archivists need to sort out the various appraisal implications. The idea that the digital systems will enable everything to be saved and ultimately retrieved has never been confirmed - and it is unlikely that it will be. As records professionals mull over the appraisal of correspondence, memoranda, financial records, 
maps, architectural drawings, sound, and moving images, they must also contemplate the implications of appraising these record forms in their newer and often still emerging digital versions. The pundits proclaiming the wonders of the Digital Era, when considering matters such as archival appraisal, just sweep it aside, declaring that there is no need for selection any longer. This seems foolhardy, as can be seen by examining a variety of other issues archivists and their repositories and community face in our modern culture. Despite the challenges of appraising the digital documentary universe, there is san immense array of documentary forms with physical attributes to be accounted for. We have long understood, for example, the limitations of copying (Tanselle, 23).

All through the 1980s archivists addressed these (and other) questions, offering guidelines on percentages of records saved, the attributes for determining intrinsic value, and procedures for selecting records to be preserved. Most of these questions re-emerged in the digital age, virtually unchanged, except for greater attention by non-archivists and non-librarians. Thomas Tanselle, Sven Birkerts, Nicholson Baker, and others questioned the loss of evidence from the destruction of the physical attributes of books and manuscripts via reformatting approaches (Baker; Birkerts; Tanselle; and my response, Cox, 2002). Scholars, from a variety of disciplines, also argued for the need to use documentary materials in their original form, even while hoping that new digital technologies enhance access to such materials (Franklin). Continuing debate led to uncertainty about decision-making schematics allowing the disposal of original materials that have been reformatted, and by the mid-1990s one microfilming manual indicated that it could make no such recommendations because it was "clear that the issue is unsettled across the archival profession" (Elkington, 3-4). These critics rejected outright the 
concept of appraisal because they resisted anyone assigning value. Terry Cook, nearly two decades ago, reflected, "Even if archivists could keep everything, they should not do so. The role of archivists is to preserve the clearest image possible of contemporary society and of its records creators by choosing the best records, not to add indiscriminately to the chaos of the information explosion by keeping too much or by keeping that which distorts or duplicates the image of the past" (Cook, 1991a, 33). Archivists, along with nearly every cultural resources management and information science discipline, have a lot of work to do about when and when not to preserve the original textual document in its physical form. The idea of saving everything digitally complicates, rather resolving, this matter.

Archivists face a variety of new challenges to their mission. While the substance of archives may change, from artifacts to virtual, the archival mission and its importance to society will remain, functioning as community memory or cultural heritage (Owens, 31). Obviously, the destruction of archives could be a way of striking at the memory and identity of a people, community, and nation, and there is an immense difference between malicious destruction and the careful, planned appraisal (allowing destruction) carried out by archivists. There is evidence that archivists don't always do appraisal as well as they should, and that many records disappear through neglect or lack of attention. We have accidental incidents of destruction (such as fire or flood), but often such accidents occur because documentary materials have not been identified, acquired, and accorded the necessary precautions. From country to country, place to place, we see neglect lead to unfortunate destruction, even when everyone recognizes the 
importance of archival records (see, for example, Locke). In the digital world, the chance of such destruction increases exponentially, as individuals and institutions can remove documents as quickly as they place them on the Web.

Getting a grip on the digital documentary heritage is critical, especially since many non-textual documentary sources, such as moving images and sound, also generally ignored in the development of appraisal criteria and selection methodologies, are becoming digital. From the very beginning of the origins of modern archival theory and practice, moving images were neglected. This lacuna is particularly seen when considering the recent work of one pioneering moving image archivist, Sam Kula, who, when he addresses the topic of appraisal, provides a partial view of appraisal approaches. The breakdown in extending appraisal approaches to such non-traditional sources can be seen when we consider ephemeral moving images such as home movies, documentaries, educational, and corporate training films - the kinds of moving images collecting dust in repositories such as historical societies, archives, and museums, when and if they make it to these institutions. Everyone becomes an archivist.

Conclusion: Looking Ahead. We need to be skeptical about the hype surrounding digital information technologies and their applications. Historians, taking the long view, remind us that every era harnessed information via innovations. Ian F. McNeely and Lisa Wolverton remind us that "Promoters of the vaunted 'information age' often forget that knowledge has always been about connecting people, not collecting information" (McNeely with Wolverton, 271). David Edgerton argues that a "futurology of the past" affects how we understand these technologies. We focus on "invention and 
innovation" and lose sight of how older technologies persist, take on new roles, and continue to be important in our society. We confuse descriptions of technology, usually written with an eye on what's ahead, with the realities of the impact, past and continuing, of the technologies themselves (Edgerton). David Nye neatly lays out how our decisions to adopt or adapt certain technologies brings with it all kinds of implications for us, from the hearth to the workplace (Nye). This is a process that suggests constantly reevaluating archival practice, tinkering with the accepted archival best practices, and negotiating with the public and those who fund and employ archivists. Archivists have a long way to go in seeing such efforts applied to a function such as archival appraisal.

Archivists need to become more proficient technically, but they also have to enhance other knowledge and skill areas. Legal issues, especially copyright, are the probable starting point now, daunting because of the often-mixed nature and origins of the documents, donor restrictions, sensitivity to family and personal privacy, and often unreliable information about ownership. Digitizing only documents with clarity of institutional ownership and rights can result in ignoring vast amounts of important archival evidence, while digitizing documents of questionable ownership can result in legal quagmires for archival programs, even as archivists are able to compile greater amounts of information about their users, follow new opportunities for teaching by providing archival documents online, and open up more powerfully archival collections for use by both scholars and the public.

The nature of archival work, the defining of archival positions, and some ancient archival principles and practices might be transformed. Long ago, Hugh Taylor advocated shucking off old textual approaches, arguing that archivists "must resist 
reading the 'new' media in a literal, textual manner and begin to learn unfamiliar grammar, syntax, and semiotics, and then teach our users to do the same" (Taylor, 186). Others have expressed similar sentiments since then (Koltun). The best archivists might do in appraisal is document what they do, something they have long espoused the benefits of in pioneering appraisal manuals (Haas, Samuels, and Simmons). More than ever before, archivists are being asked to justify the decisions they have made to their employers, constituents, and the public. Checklists, descriptions of procedures, and general mission statements no longer will suffice. As Terry Cook describes "exemplary selection," archivists must be able to explain, in order to be accountable, just what they are doing in their appraisal work (Cook, 1991a, 39-41).

Archivists need to admit their fallibilities, mistakes, and problems in conducting appraisal, as well as acknowledging that the public really does not understand how archives are formed (nor, for that matter, do many of the researchers using archives). One of the challenges may be due to the lack of standardized appraisal approaches and efforts to analyze appraisal results and implications, as Jennifer Marshall determined in her study on the collection policies of academic archives (Marshall, 2002). Marshall also has made a major contribution to our understanding of appraisal documentation for accountability purposes in her comparative analysis of the national archives of Australia, Canada, and the United States, discovering that while all three institutions produce a range of documentation regarding this important archival function, there is still much to be done regarding making the appraisal process transparent (Marshall, 2006).

Appraisal documentation is necessary since the nature of the new digital documentary universe requires re-thinking appraisal as a continuous rather than one-time 
process (as it has often been thought of). Archivists have long known that many of the larger collections or fonds they bring into their repositories create challenges with their bulk versus their quality of evidence, as Leonard Rapport reminds us (Rapport). While there has been a modest amount of research done about how archivists use re-appraisal, the evidence seems to be that it is viewed by most as conceptually acceptable but as impractical in application (too many other pressing tasks and not enough time).

Archival appraisal may be the core function, but it is under-developed and needs to be re-focused on the fluid digital documentary universe. We are living in a land that may seem foreign to many of us. Most of us grew up in an analog and textual world, and our interests in archives were shaped by the prospects of working with old documents, printed ephemera, and other old stuff. It may surprise some to know that the majority of individuals attracted to graduate archival education programs still come with romantic notions of what archivists do and what they work with. While some get energized with deep challenges posed by the digital documentary universe, others complain and sometimes drop out. If one is looking for fascinating challenges, these are good times indeed.

We have more predictions about the transformation of society by the digital technologies than careful study and reflection about the actual impacts. Ones with particular implications for archivists and appraisal in the Digital Era include the convergence of disciplines, the rise of new professions and the end of old ones, and the empowerment of ordinary citizens to become their own experts.

Convergence runs the risk of eliminating the distinctive sense of the archivist and the possibility of weakening the archival mission by embracing trendier notions (digital 
curators rather than archivists, cyberspecialists rather than librarians, and interdisciplinarity at the expense of a focused mission). However, the risk might be worth it. Within universities new research centers are regularly created, intended to bring together faculty and graduate students from a variety of departments and even individuals from outside the university (such as in corporations), opening up the possibility of supporting the creation and sustenance of a new kind of digital archivist who could apply old approaches, such as appraisal, to the digital universe. I sometimes tell my students that there may not be a profession known as archives in the future, meaning that what we are called may one day change and the primary nature of our work (although all this may make communicating our mission much easier as the public engages more deeply in digital personal archives and online work). Armed with a modestly priced laptop the average person can create virtual archives, publish books, and access more information, consolidating all of the roles from information consumer to information creator, from reader to publisher, from archival researcher to archival custodian.

Some of what we are seeing happen is due to what has been labeled Web 2.0, the use of the Web to allow and promote social networking through approaches such as wikis, blogs, and so forth. Add to this Web 3.0 with a stronger stress on eliminating gatekeepers, and we see even different roles for archivists and their allies in the future. Obviously, archivists ought to be involved in such activities, enhancing how they work with the users of archival sources in an online environment. Whether researchers cease to come to physical spaces known as archives (or libraries or museums) may not be the issue; the issue is that how researchers interact with archival sources will be more varied and complex than anything we have experienced before. The continued evolution, and 
growing power, of the Web will have dramatic impacts on how archivists and librarians function and what their future will be. It will certainly transform how archivists must rethink appraisal.

One of the primary issues archivists need to deal with in the Digital era is the notion that everything can be saved, directly challenging the idea of archival appraisal. The belief in this is pervasive, from individuals developing software, such as MyLifeBits, to record everything, to leaders (and many followers) in the library, information, and computer sciences fields who regularly state such a belief. The idea that everything can be saved may be the mantra of the digital true believer. Not only does this idea and its supporters ignore the other technical issues of retrieval, the ability to retrieve and retain important contextual meaning, and the costs of maintenance, the reason for or logic behind saving everything is usually avoided.

The archival community can make a contribution here, if it wills itself to look beyond the false promises of saving everything. I was challenged about this at a conference, confronted with the idea that technicians tell us this can be done; my response was that archivists are not technicians, but play other roles (such as selectors). While archival appraisal practice has been weaker than it should be, the theoretical and methodological literature is quite interesting and useful for such tasks in the digital universe. Over the course of more than a half-century, archivists have articulated appraisal schemes using values of records, more precise definitions of records, macro approaches considering the reasons for recordkeeping, functional analysis, sampling models, intrinsic values of records (or, records as artifacts or the symbolic value of documents), documentation strategies, and reappraisal methodologies. Archivists (at 
least those engaged in this function) have accumulated a high level of expertise about the means of identifying the evidence and information found in documents of all sorts, even if their application in the digital realm has been limited and their efforts to work with other fields (such as preservation administrators) have been just as limited. What archivists need now to do is to develop new versions of the appraisal approaches to be applied effectively to the digital documentary universe and, just as importantly, evaluate some of the approaches for dealing with this universe, such as the Internet Archive (really a sampling method).

From my vantage, appraisal is the core, critical function of archival work. For more than a hundred years, individuals in the modern archival community have discussed the challenges posed by the immense scope of the documentary universe (I have tried to present my own views on archival appraisal in my 2004 book). Yet, I am sure archivists agree that the scope of the present documentary universe is far more complex and larger than anything we have considered before (or ever could have imagined). And, when we consider such shifting identities, different missions or greatly re-engineered methodologies, it is when we wonder just how much chaos we can really handle or how much confusion we might bring upon ourselves.

Technology is not the major challenge facing archivists in their work. Now I see the main challenge as being an expansion of the archival mission from just a cultural role to one encompassing ethics and accountability matters, issues that have been exaggerated in significance partly because of the increasing powerful applications of the digital information technologies. Records and recordkeeping systems, especially as they move deeper into the digital realm, pose greater problems with intellectual property, 
preservation, and privacy. The cultural mandate remains (and always will be the main attraction for many), but it is also the case that corporate, government, and academic archives will generate more and more instances where archivists are called upon both to help records creators and users guarantee access to documents and to assist the organizations defend themselves (sometimes in unethical or illegal ways resulting in individual archivists needing to consider their own ethical and moral foundations) (Cox and Wallace; Cox, 2006).

What we need to key in on is the preparation of a new generation of archivists, professionals who have the knowledge of the history of recordkeeping systems, traditional archival principles (traditional in the sense that they are based on older recordkeeping systems and forms), and new and emerging digital information systems (including a solid working understanding of new digital document forms). Archivists will be more documentary shapers than documentary custodians, more digital forensic experts than documentary describers, and more archival activists than passive reference gatekeepers. How do we prepare this new generation of archivists? Our graduate archival education programs are, at best, a mixed bag. Are they able to offer a comprehensive enough curriculum for Digital Era archivists? Graduate archives programs have nearly all shifted to LIS schools and, while there, some of these schools have made a shift to Information Schools (I-Schools). It is in these programs, however, that we have the best chance to inspire new perspectives, build new leadership, and develop new principles for what looms ahead in both our profession and our broader culture. These opportunities have been enhanced in the rebirth of LIS schools as I-Schools, now addressing concerns such as the curation and preservation of primary and secondary sources that are born- 
digital, the life cycle/continuum concept of records, the preservation imperative, cultural and humanistic perspectives, public and institutional memory, the evolving notion of records in the digital era, and the implications of new portable digital technologies on issues such as the creation, maintenance, and use of records and information sources deemed to possess long-term archival value.

Archivists have a lot of opportunities and challenges ahead of them. Patricia Zimmerman's contribution to a recent volume of essays on home movies describes how "home movies constitute an imaginary archives that is never completed, always fragmentary, vast, infinite." She also adds that, "In the popular imagination, archives often are framed as the depositories of old, dead cultural artifacts. But archives are never inert, as they are always in the process of addition of new arenas and unknown objects. The archive, then is, is not simply a depository, which implies stasis, but is, rather, a retrieval machine defined by its revision, expansion, addition, and change" (Zimmerman in Ishizuka and Zimmerman, 18, 20). Such concerns upset some, but these reflect the new reality we are dealing with, and, more importantly, suggest some wonderful new opportunities. As we reflect on functions such as appraisal, we need to be prepared to evolve in our approaches, perhaps at a rate much faster than archivists have been accustomed to doing.

\section{List of Works Cited}

Abraham, Terry (1995). "Documentation Strategies: A Decade (or More) Later," paper presented at the Society of American Archivists, Washington D.C., available at http://www.uidaho.edu/special-collections/papers/docstr10.htm.

Anderson, Byron (1999). "What's Worth Digitizing?," Behavioral \& Social Sciences Librarian 18, 75-77. 
Astle, Peter J. and Adrienne Muir (2002). "Digitization and Preservation in Public Libraries and Archives," Journal of Librarianship and Information Science 34, no. 2, 6779.

Baker, Nicholson (2001). Double Fold: Libraries and the Assault on Paper. New York: Random House.

Barksdale, Jim and Francine Berman (16 May 2007). "Saving Our Digital Heritage," Washington Post, A15.

Bearman, David (1995). “Archival Strategies,” American Archivist 58 (Fall): 381-413.

Birkerts, Sven (1994). Gutenberg Elegies: The Fate of Reading in the Electronic Age. Boston: Faber and Faber.

Boles, Frank and Julia Marks Young (1985). "Exploring the Black Box: the Appraisal of University Administrative Records," American Archivist 48 (Spring), 121-140.

Booms, Hans (1987). "Society and the Formation of a Documentary Heritage: Issues in the Appraisal of Archival Sources," Archivaria 24 (1987), 69-107.

Borgman, Christine L. (2007). Scholarship in the Digital Age: Information, Infrastructure, and the Internet. Cambridge, MA: MIT Press, 2007.

Bradley, Harriet (1999). "The Seductions of the Archive: Voices Lost and Found," History of the Human Sciences 12, no. 2, 107-122.

Brown, Richard (1991-92). "Records Acquisition Strategy and its Theoretical Foundation: The Case for a Concept of Archival Hermeneutics," Archivaria, 33 (Winter), 34-56.

Carlson, Scott (9 February 2007). "On The Record, All the Time: Researchers digitally capture the daily flow of life. Should they?" Chronicle of Higher Education, 53, p. A30.

Carr, Nicholas (2008). "Is Google Making Us Stupid?" Atlantic302 (July/August): 56-58, 60, 62-63.

Childs, Margaret S. (1990). "Selection for Microfilming," American Archivist 53 (Spring), 250-255.

Clifford, Theresa (14 February 2007). "Is Wikipedia Part of a New 'Global Brain'?" Spiked, http://www.spiked-online.com/index.php?/site/article/2852/, accessed February 14, 2007.

Conway, Paul (1990). "Archival Preservation Practice in a Nationwide Context," American Archivist 53 (Spring), 204-222. 
Conway, Paul (1992). "Preserving History's Future: Developing a Nationwide Strategy for Archival Preservation" in Advances in Preservation and Access, vol. 1 ed. Barbra Buckner Higginbotham and Mary E. Jackson. Westport, CT: Meckler, 244-260.

Cook, Terry (1991). The Archival Appraisal of Records Containing Personal Information: A RAMP Study with Guidelines. Paris: UNESCO.

Cook, Terry (1991a). “Many are called but few are chosen': Appraisal Guidelines for Sampling and Selecting Case Files," Archivaria 32 (Summer), 25-50.

Cook, Terry, (2001). "Fashionable Nonsense or Professional Rebirth: Postmodernism and the Practice of Archives," Archivaria 51 (Spring), 14-35.

Cook, Terry (1992). "Mind Over Matter: Towards A New Theory of Archival Appraisal," in Barbara L. Craig, ed., The Archival Imagination: Essays in Honour of Hugh A. Taylor. Ottawa: Association of Canadian Archivists, 38-70.

Cox, Richard J. (2002). Vandals in the Stacks? : A Response to Nicholson Baker's Assault on Libraries. Westport, Connecticut: Greenwood Press.

Cox, Richard J. (2004). No Innocent Deposits: Forming Archives by Rethinking Appraisal. Metuchen, N.J.: Scarecrow Press.

Cox, Richard J. (2006). Ethics, Accountability and Recordkeeping in a Dangerous World. London: Facet.

Cox, Richard J. and David Wallace, eds. (2002), Archives and the Public Good: Accountability and Records in Modern Society. Westport, Conn.: Quorum Books.

Cunningham, Adrian (1996). "Beyond the Pale? The 'Flinty' Relationship between Archivists Who Collect the Private Records of Individuals and the Rest of the Archival Profession," Archives and Manuscripts 24 (May), 20-27.

Daniels-Howell, Todd (1998). "Reappraisal of Congressional Records at the Minnesota Historical Society: a Case Study," Archival Issues 23, no. 1, 35-40.

Darnton, Robert (12 June 2008). "The Library in Your Future," New York Review of Books 55, 72-73, 76, 78-80.

Deegan, Marilyn and Simon Tanner, eds. (2006). Digital Preservation. London: Facet Publishing.

De Stefano, Paula (2000). "Selection for Digital Conversion," Moving Theory into Practice: Digital Imaging for Libraries and Archives, eds. Anne R. Kenney and Oya Y. Rieger. Mountain View, CA: Research Libraries Group, 11-23. 
Edgerton, David (2007). The Shock of the Old: Technology and Global History Since 1900. New York: Oxford University Press.

Elkington, Nancy E., ed. (1994). RLG Archives Microfilming Manual (Mountain View, California: Research Libraries Group.

Ericson, Timothy (2000). " At the Rim of Creative Dissatisfaction: Archivists and Acquisition Development," in American Archival Studies: Readings in Theory and Practice, ed., Randall C. Jimerson. Chicago: Society of American Archivists.

Foote, Kenneth E. (1990). "To Remember and Forget: Archives, Memory, and Culture," American Archivist 53 (Summer), 378-392.

Franklin, Phyllis (1993). "Scholars, Librarians and the Future of Primary Records" College and Research Libraries 54 (September), 397-406.

Friedman, David D. (2008). Future Imperfect: Technology and Freedom in an Uncertain World. New York: Cambridge University Press, 2008.

Gardner, Howard (2006). Five Minds for the Future. Boston: Harvard Business School Press.

Gertz, Janet (2000). "Selection for Preservation in the Digital Age," Library Resources and Technical Services 44, no. 2 , 97-104.

Gracy, David B. (1975). "Peanut Butter and Spilt Milk; A New Look at Collecting," Georgia Archive 3 (Winter), 20-29.

Greene, Mark A. (1994). "Appraisal of Congressional Records at the Minnesota Historical Society: A Case Study,” Archival Issues 19 no. 1, 31-43.

Guess, Andy (30 May 2008). "Post-Microsoft, Libraries Mull Digitization," Inside Higher Education, available at http://insidehighered.com/news/2008/05/30/microsoft, accessed May 30, 2008.

Guess, Andy (17 June 2008). "Research Methods 'Beyond Google,"” Inside Higher Education, available at http://insidehighered.com/news/2008/06/17/institute, accessed June 17, 2008.

Guess, Andy (23 July 2008). “At Libraries, Taking the (Really) Long View,” Inside Higher Education, available at http://insidehighered.com/news/2008/07/23/preservation, accessed July 23, 2008.

Haas, Joan K., Helen W. Samuels and Barbara T. Simmons (1985). Appraising the Records of Modern Science and Technology: A Guide. Cambridge: MIT Press, 1985. 
Haas, Richard L. (1984). "Collection Reappraisal: the Experience at the University of Cincinnati," American Archivist 47 no. 1 (Winter): 51-54.

Ham, F. Gerald (1992). Selecting and Appraising Archives and Manuscripts. Chicago: Society of American Archivists.

Harris, Verne (2001). "On the Back of the Tiger: Deconstructive Possibilities in 'Evidence of Me'," Archives and Manuscripts 29 (May), 8-21.

Hazen, Dan, Jeffrey Horrell, and Jan Merrill-Oldham (1998). "Selecting Research Collections for Digitization," Microfilm and Imaging Review 27, no. 3, 82-93

Hess, Charlotte and Elinor Ostrom (2007). Understanding Knowledge as a Commons: From Theory to Practice. Cambridge, MA: MIT Press.

Howard, Jennifer (26 August 2008). "Scholars' View of Libraries as Portals Shows Marked Decline," Chronicle of Higher Education, http://chronicle.com/daily/2008/08/4351n.htm, accessed August 26, 2008.

Ishizuka, Karen L. and Patricia R. Zimmerman, eds. (2008). Mining the Home Movie: Excavations in Histories and Memories. Berkeley: University of California Press.

Jeanneney, Jean-Noël (2007). Google and the Myth of Universal Knowledge: A View from Europe, trans. Teresa Lavender Fagan. Chicago: University of Chicago Press.

Keen, Andrew (2007). The Cult of the Amateur: How Today's Internet is Killing Our Culture. New York: Doubleday/Currency.

Ketelaar, Eric (2002). "Archival Temples, Archival Prisons: Modes of Power and Protection," Archival Science 2, 221-238.

Kolish, Evelyn (1994). "Sampling Methodology and its Application: An Illustration of the Tension Between Theory and Practice," Archivaria 38 (1994), 61-73.

Koltun. Lilly (1999). "The Promise and Threat of Digital Options in an Archival Age." Archivaria 47 (Spring), 114-135.

Levy, David M. (2006). "More, Faster, Better: Governance in an Age of Overload, Busyness, and Speed," First Monday, special issue number 7 (September), available at http://firstmonday.org/issues/special11_9/levy/index.html.

Locke, Ian F. (1993). "Archive Destruction and Dispersal in the UK - An Elementary Overview," Journal of the Society of Archivists 14, no. 1, 7-13. 
Marshall, Jennifer A. (2002). "Toward Common Content: An Analysis of Online College and University Collecting Polices," American Archivist 65, no. 2 (Fall/Winter), 231-256.

Marshall, Jennifer A. (2006). “Accounting for Disposition: A Comparative Case Study of Appraisal at the National Archives and Records Administration in the United States, Library and Archives Canada, and the National Archives of Australia." Unpublished Ph.D. dissertation, University of Pittsburgh.

McNeely, Ian F. with Lisa Wolverton (2008). Reinventing Knowledge: From Alexandria to the Internet. New York: W. W. Norton \& Co.

McKemmish, Sue (1996). "Evidence of Me..." Archives and Manuscripts 24 (May), 2745.

MacNeil, Heather (2001). "Trusting Records in a Postmodern World," Archivaria 51 (Spring), 36-47.

National Science Foundation (2007). Cyberinfrastructure Vision for 21st Century Discovery (March).

Nesmith, Tom, (2002). "Seeing the Archives: Postmodernism and the Changing Intellectual Place of Archives," American Archivist 65 (Spring/Summer), 24-41.

Norman, Donald (2007). The Design of Future Things. New York: Basic Books.

Nye, David E. (2006). Technology Matters: Questions to Live With. Cambridge, MA: MIT Press.

Owens, Brian M. (2003). "The Safeguarding of Memory: The Divine Function of the Librarian and Archivist," Library and Archival Security 18, no. 1 (2003), 9-41.

Palfrey, John and Urs Gasser (2008). Born Digital: Understanding the First Generation of Digital Natives. New York: Basic Books.

Powell, Sheila (1991-92). “Archival Reappraisal: The Immigration Case Files," Archivaria 33 (Winter), 104-116.

Rapport, Leonard (1981). "No Grandfather Clause: Reappraising Accessioned Records," American Archivist 44 (Spring), 143-150.

Rein, Laura (5 January 2007). "The Changing 'Place' of the Library," Inside Higher Education, available at http://insidehighered.com/views/2007/01/05/rein, accessed January 5, 2007. 
Samuels, Helen W. (1986). "Who Controls the Past," American Archivist 49 (Spring), 109-124.

Schaeffer, Roy C. (1992). "Transcendent Concepts: Power, Appraisal, and the Archivists as "Social Outcast," American Archivist 55 (Fall), 608-619

Schwartz, Joan M. and Terry Cook (2002). "Archives, Records, and Power: The Making of Modern Memory," Archival Science 2, 1-19.

Shillingsburg, Peter L. (2006). From Gutenberg to Google: Electronic Representations of Literary Texts. Cambridge: Cambridge University Press.

Shirky, Clay (2008). Here Comes Everybody: The Power of Organizing Without Organizations. New York: Penguin Press.

Sink, Robert (1990). “Appraisal: The Process of Choice," American Archivist 53, no. 3 (Summer): 452-458.

Smith, Abby (1999). Why Digitize? Washington, D.C.: Council on Library and Information Resources.

Snelson, Pamela (29 March 2007). "Libraries at the Cutting Edge," Inside Higher Education, available at http://insidehighered.com/views/2007/03/29/snelson, accessed March 29, 2007.

Stephens, David O. (1998). "Megatrends in Records Management," Records Management Quarterly 32 (January), 3-9.

Upward, Frank Upward and Sue McKemmish (1994). "Somewhere Beyond Custody," Archives and Manuscripts, 22, no. 1, 136-149.

Tanselle, Thomas (1998). Literature and Artifacts. Charlottesville: The Bibliographic Society of the University of Virginia.

Taylor, Hugh (2003). Imagining Archives, eds. Terry Cook and Gordon Dobbs. Lanham, MD: Scarecrow Press for the Society of American Archivists.

Tough, Alistair and Michael Moss, eds., (2006). Record Keeping in a Hybrid Environment: Managing the Creation, Use, Preservation and Disposal of Unpublished Information Objects in Context. Oxford, England: Chandos Publishing,.

Vogt-O'Connor, Diane (2000). "Selection of Materials for Scanning," Handbook for Digital Projects: A Management Tool for Preservation and Access, ed. Maxine K. Sitts. Andover, MA: Northeast Document Conservation Center, available at http://www.nedcc.org/digital/dman.pdf. 
Wilson, Mark A. (1 April 2008)., "Professors Should Embrace Wikipedia," Inside Higher Education, http://insidehighered.com/views/2008/04/01/wilson, accessed April 1, 2008.

Wright, Alex (2007). Glut: Mastering Information Through the Ages. Washington, D.C.: Joseph Henry Press, 2007.

Zorich, Diane M., Günter Waibel and Ricky Erway (2008). Beyond the Silos of the LAMs: Collaboration Among Libraries, Archives and Museums. Dublin, Ohio: OCLC Online Computer Library Center, Inc. 